\title{
Correlation Analysis of Mineral Element Content and Sensory Quality of National Geographical Sign Product--Olecranon Peaches in Lianping
}

\author{
Pi Xiaodi ${ }^{1,2}$, Li Yeqing ${ }^{3, *}$, Xie Xiting $^{2}$ and Xu Hongyong ${ }^{2}$ \\ ${ }^{1}$ Guangdong JiangMen Chinese Medical College, 529000 Guangdong,China \\ ${ }^{2}$ Guangdong Heyuan Quality Metrology Supervision and Inspection Institute, 517000 Guangdong,China \\ ${ }^{3}$ Heyuan Polytechnic, 517000 Guangdong,China
}

\begin{abstract}
Microwave digestion-inductively coupled plasma astigmatism (ICP-AES) was used to analyze the contents of mineral elements (including $\mathrm{K}, \mathrm{P}, \mathrm{Mg}, \mathrm{Ca}, \mathrm{Na}, \mathrm{Fe}, \mathrm{Cu}, \mathrm{Mn}, \mathrm{B}, \mathrm{Zn}, \mathrm{Se}, \mathrm{Li}$ ) in 54 Olecranon Peaches collected from Shangping town, Lianping County. The obtained data was analyzed by Correlation analysis (CA), combined with fruit reducing sugar (RS\%), sugar-acid ratio (S/A) and sensory scores. The results showed that in the tested samples, it had a significant positive correlation between S/A sugar-acid ratio and sensory evaluation. S/A was negatively correlated with $\mathrm{P}$ contents. The $\mathrm{P}$ contents were positively correlated with the $\mathrm{K} 、 \mathrm{Mg}$ contents. The $\mathrm{Mg}$ contents were positively correlated with the $\mathrm{K} 、 \mathrm{Na}$ contents. The Na contents were positively correlated with the Mn contents. The contents of Mn were positively correlated with $\mathrm{RS} \%$ ratios of reducing sugar.
\end{abstract}

\section{Introduction}

Lianping Olecranon Peache, a hard meat peach species, named for the shape of an Eagle's beak, mainly was produced in Shangping Town, Lianping County, Heyuan City, Guangdong Province. Olecranon Peache is the best peach variety in Guangdong and even in the south of China. It is praised by agricultural experts as "the ultimate peach product ".

Mineral elements are indispensable for fruit growth and development. Its kinds and contents are also one of the important indexes to measure its nutritional value. The traceability index of mineral elements in different foods are different. Lu Baoxin et.al[1] showed that analysis of mineral content data was useful for tracing the geographical origin of soybeans from different producing areas in the province. And six metal elements, $\mathrm{Na}, \mathrm{K}, \mathrm{Mn}, \mathrm{Rb}, \mathrm{Ba}$ and $\mathrm{Au}$, were identified as indicators for traceability analysis. Borges et.al[2] sifted out that As, $\mathrm{B}, \mathrm{Ba}, \mathrm{Cd}, \mathrm{Co}, \mathrm{Cr}, \mathrm{Cu}, \mathrm{Fe}, \mathrm{K}, \mathrm{Mg}, \mathrm{Mn}, \mathrm{P}, \mathrm{Rb}$ and $\mathrm{Zn} 14$ elements were selected to identify the differences between organic and common rice. Zhao et.al[3] screened out $\mathrm{Na}, \mathrm{Ca}, \mathrm{Fe}, \mathrm{Zn}$ and Mo from wheat and soil samples from three different producing areas in China. Zheng Hui [4] analysed and sifted out five elements( $\mathrm{Mg}$, $\mathrm{Cg}, \mathrm{Ng}, \mathrm{Mn}$ and $\mathrm{Zn}$ ) with high local attribute of Liuhe County Rice. Zhang Yue et.al[5] achieved a small range of origin traceability, the trace elements of $\mathrm{Zn}, \mathrm{K}, \mathrm{Mg}$, $\mathrm{Na}, \mathrm{Ca}$ and $\mathrm{Mn}$ in Songyuan were obtained by using mineral elements. $\mathrm{Mn}, \mathrm{Fe}, \mathrm{Co}, \mathrm{Cu}, \mathrm{Zn}, \mathrm{Se}, \mathrm{Rb}, \mathrm{Sr}, \mathrm{Ba}, \mathrm{Pb}$,
$\mathrm{Ca}, \mathrm{Mg}, \mathrm{Na}$ were verified to determine the origin of milk powder by Dang et.al[6]. Zhao Qian [7] thought that Zn, $\mathrm{Pb}, \mathrm{Fe}, \mathrm{Mg}, \mathrm{Cu}$ in Meihe Rice have good stability and space representativeness, which can be used as the confirmation index of rice producing area.

Organic component traceability is also one of the effective analysis methods to evaluate the quality of famous and special products and to distinguish the origin of food. The traceability model established by Wang Kaiqiang [8] using Gas Chromatography to detect fatty acids in pork was better than that established by nuclear magnetic resonance technique. And the accuracy was $100 \%$. The correct discrimination rate of soybean monomers, such as Daidzin, Glycitin and Genistein, screened by Liu Wenjing [9] was $81.1 \%$, which met the requirements of the discrimination analysis of soybean origin.

In 2015, permission was granted for Lianping Olecranon Peaches to be protected with a geographical sign product. Olecranon Peaches are not only planted in Lianping, but also Fujian Longyan, Wuping Yao Lu , Guangdong Wengyuan (Jiuxian peach). In addition, near the surrounding areas of Lianping there are planting olecranon peach, such as Liyuan Town Heping County, Tianxin Town Longchuan County. But Lianping Olecranon Peachs, especially Shangping are the most delicious as consumers reflected. For the protection of national geographical sign products and the need of construction of Olecranon Peache industry park in Lianping County, it has great significance to analyze the

\footnotetext{
*Corresponding author: belys2000@126.com
} 
mineral element content and nutrient content of Lianping Olecranon Peache, and to establish a discriminant model combined with sensory evaluation.

\section{Materials and methods}

\subsection{Materials and reagents}

Olecranon Peaches: Obtained from Shangping Town, Lianping County

The standard solution concentration of 12 mineral elements $(\mathrm{K}, \mathrm{P}, \mathrm{Mg}, \mathrm{Ca}, \mathrm{Na}, \mathrm{Fe}, \mathrm{Cu}, \mathrm{Mn}, \mathrm{B}, \mathrm{Zn}, \mathrm{Se}, \mathrm{Li})$ is all $1 \mathrm{mg} / \mathrm{mL}$ : purchased from the General Institute of Iron and Steel Research of the National Iron and Steel Materials testing Center; Concentrated Nitric Acid (excellent grade pure): purchased from Shanghai Chinese Medicines Chemical Reagent Co., Ltd.; Ultrapure Water: laboratory self-made (conductivity $18.2 \mathrm{M} \Omega$ )

\subsection{Instruments and equipments}

7000DV inductively coupled plasma divergence spectrometer (PERKINELMER US); ETHOS One microwave digestion / extraction system (Beijing Lebertaic instrument Co., Ltd.); AL104 electronic balance (Mettler-Toledo, US).

\subsection{Determination of mineral elements in Olecranon Peaches}

\subsubsection{Fruit Pretreatment}

The samples were peeled and nucleated after ultra-pure water washing and controlled dry water, evenly distributed, and divided into two parts.A part was placed in a fresh-keeping bag- $80^{\circ} \mathrm{C}$ frozen and stored, and the other part was used for sensory evaluation and nutritional determination.

\subsubsection{Microwave digestion and analysis of samples}

The $0.5000 \mathrm{~g}$ sample was taken and placed in the polytetrafluoroethylene(PTFE) microwave digestion tank, with $6 \mathrm{~mL}$ of concentrated nitric acid, the inner cover was covered and the coat was tightened, and the microwave digestion system was put in. The digestion conditions were shown in table 1 . After digestion, cooled to $60-70^{\circ} \mathrm{C}$ temperature in the tank, removed the digestion tank from the ventilation cabinet to remove acid, transfered the solution to $10 \mathrm{~mL}$ capacity bottle, fixed the volume with ultra-pure water, mixed well and set aside. A 7000 DV ICP-AES was used to determine the content of 12 mineral elements in the samples.

Table 1 Microwave digestion conditions

\begin{tabular}{ccccc}
\hline Steps & $\mathrm{t} / \mathrm{min}$ & $\theta /{ }^{\circ} \mathrm{C}$ & $\mathrm{p} / \mathrm{MPa}$ & $\mathrm{P} / \mathrm{W}$ \\
\hline 1 & 5 & 100 & 1.0 & 800 \\
2 & 8 & 120 & 1.5 & 800 \\
3 & 5 & 140 & 2.0 & 800 \\
\hline
\end{tabular}

\subsection{Determination of Nutrient Components of Olecranon Peaches}

Direct titration was used for the determination of reducing sugar(RS) according to GB 5009.7-2016. GB 5009.8-2016 was used for determination of total soluble sugar (S)with acid hydrolysis titration. GB 5009.2392016 was used for determination of titratable acid (A) with $\mathrm{NaOH}$ titration. Reduction sugar ratio $(\mathrm{RS} \%)=$ reducing sugar content / soluble total sugar content 100; sugar-acid ratio $(\mathrm{S} / \mathrm{A})=$ soluble total sugar content $/$ titratable acid content.

\subsection{Sensory evaluation of Olecranon Peaches}

Nine peach evaluators were invited to conduct training, and then the color, taste and aroma of the Olecranon Peaches were evaluated. The scoring table is shown in table 2.

Table 2 Grades of Sensory Quality of Olecranon Peaches

\begin{tabular}{|c|c|c|c|}
\hline $\begin{array}{l}\text { Item } \\
\text { score }\end{array}$ & Colour $(20 \%)$ & Palate (40\%) & $\begin{array}{l}\text { Aroma } \\
(40 \%)\end{array}$ \\
\hline 100 & $\begin{array}{l}\text { The coloring is very } \\
\text { even, the surface is } \\
\text { very smooth }\end{array}$ & $\begin{array}{l}\text { The flesh is very } \\
\text { delicate, juicy } \\
\text { and taste good }\end{array}$ & $\begin{array}{l}\text { Fruity is } \\
\text { strong }\end{array}$ \\
\hline 80 & $\begin{array}{l}\text { The coloring is } \\
\text { even, the surface is } \\
\text { smooth }\end{array}$ & $\begin{array}{l}\text { Delicate, juicy, } \\
\text { good taste }\end{array}$ & $\begin{array}{l}\text { Fruit } \\
\text { rich }\end{array}$ \\
\hline 60 & $\begin{array}{l}\text { The coloring is less } \\
\text { even. It's got a } \\
\text { smooth surface }\end{array}$ & $\begin{array}{l}\text { The pulp is more } \\
\text { delicate, juicy } \\
\text { and taste better }\end{array}$ & $\begin{array}{l}\text { Strong } \\
\text { fruit } \\
\text { aroma }\end{array}$ \\
\hline 40 & $\begin{array}{l}\text { The coloring is } \\
\text { uneven and the } \\
\text { surface is less } \\
\text { smooth }\end{array}$ & $\begin{array}{l}\text { Rough pulp, less } \\
\text { juice, less taste }\end{array}$ & $\begin{array}{c}\text { Fruity is } \\
\text { light }\end{array}$ \\
\hline 20 & $\begin{array}{l}\text { The coloring is } \\
\text { uneven and the } \\
\text { surface is not } \\
\text { smooth }\end{array}$ & $\begin{array}{l}\text { Rough pulp, less } \\
\text { juice, poor taste }\end{array}$ & $\begin{array}{l}\text { Light } \\
\text { fruit }\end{array}$ \\
\hline 0 & $\begin{array}{l}\text { The color is very } \\
\text { uneven. The surface } \\
\text { is extremely } \\
\text { unpolished }\end{array}$ & $\begin{array}{l}\text { The pulp is very } \\
\text { rough, very little } \\
\text { juice, very poor } \\
\text { taste }\end{array}$ & $\begin{array}{c}\text { Fruity is } \\
\text { light }\end{array}$ \\
\hline $\begin{array}{l}\text { Score } \\
\text { Total }\end{array}$ & & & \\
\hline
\end{tabular}

\subsection{Data analyses}

The correlation analysis (CA) was carried out by SPSS 23.0 software to find out the mineral elements and nutrient components significantly related to the sensory evaluation of Olecranon Peaches.

\section{Results and Analyses}

\subsection{Trace element content of Olecranon Peaches}

According to 1.3 method, the mineral elements content of Olecranon Peachest were determined. The results were shown in Fig.1-12. (FW means fresh fruit weight. ) 


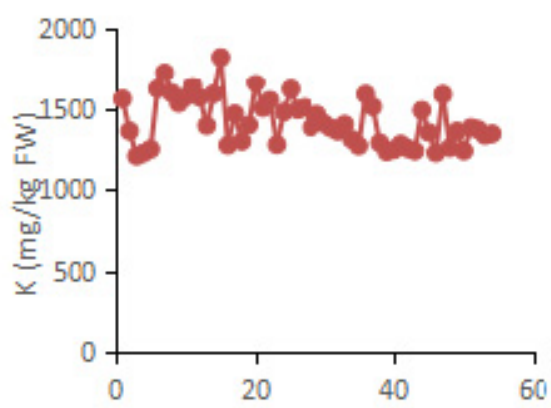

Fig.1 Contents of K in 54 samples

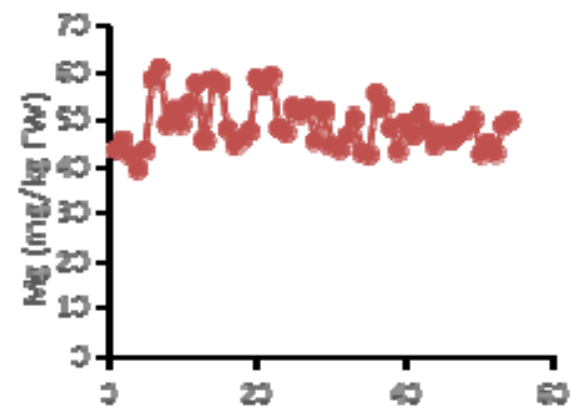

Fig.2 Contents of Mg in 54 samples

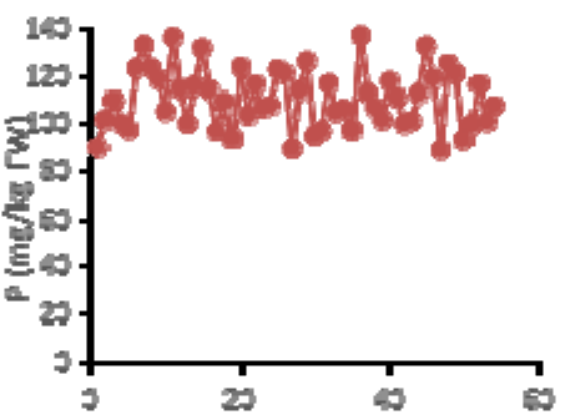

Fig.3 Contents of P in 54 samples
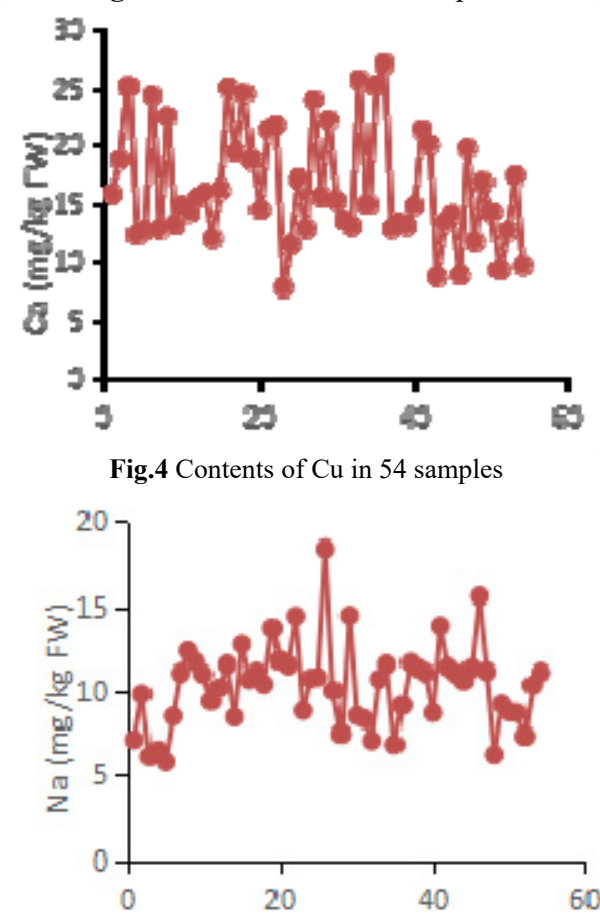

Fig.5 Contents of $\mathrm{Na}$ in 54 samples

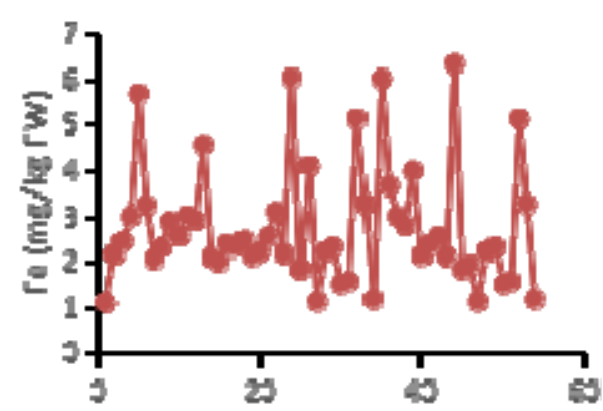

Fig.6 Contents of $\mathrm{Fe}$ in 54 samples

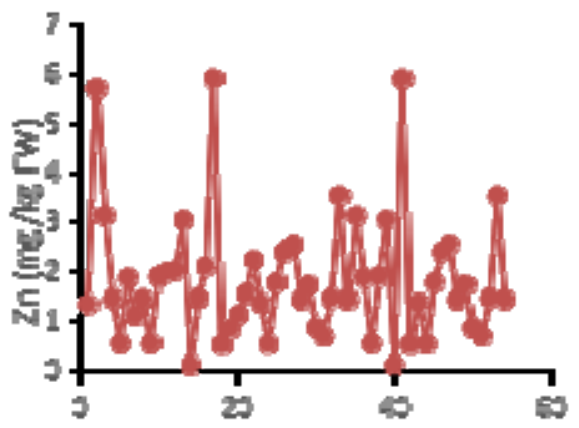

Fig.7 Contents of $\mathrm{Zn}$ in 54 samples

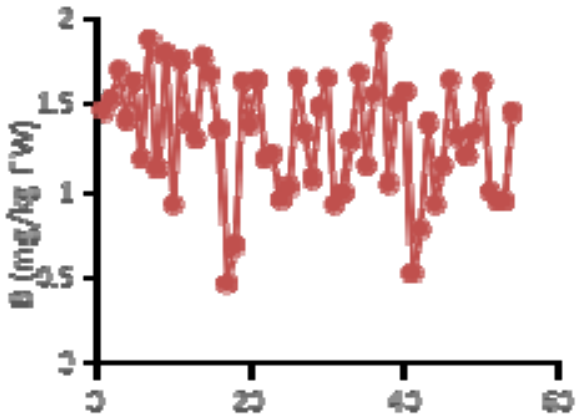

Fig.8 Contents of B in 54 samples

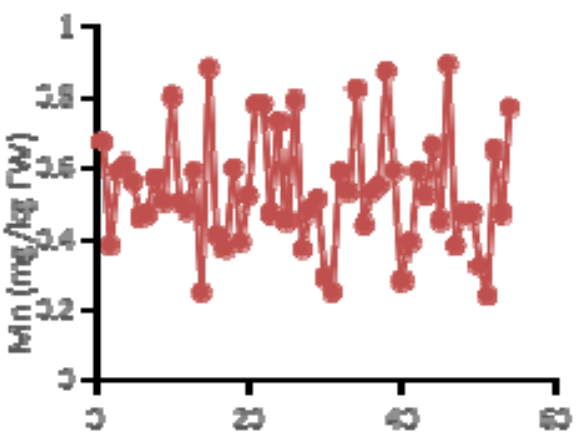

Fig.9 Contents of Mn in 54 samples

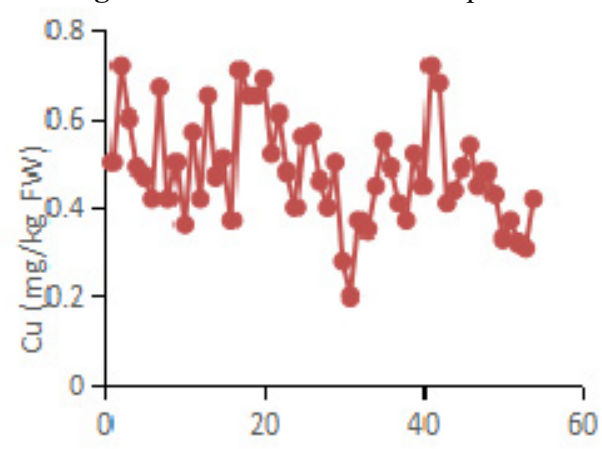

Fig.10 Contents of $\mathrm{Cu}$ in 54 samples 


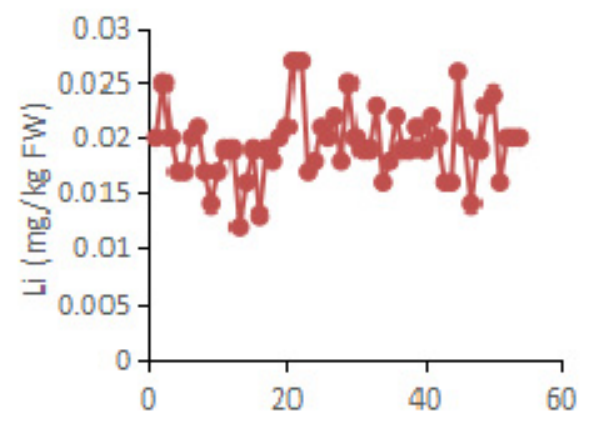

Fig.11 Contents of Li in 54 samples

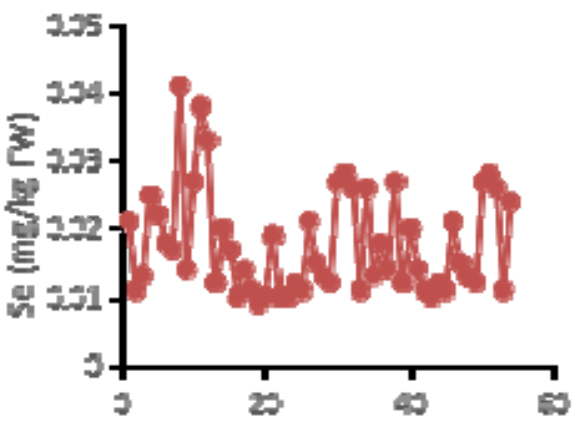

Fig.12 Contents of Se in 54 samples

Fig.1-12 showed that, in the 54 samples tested, The K contents were between $1205-1820 \mathrm{mg} / \mathrm{kg}$. The $\mathrm{Mg}$ contents were between $39.29-60.65 \mathrm{mg} / \mathrm{kg}$. The $\mathrm{P}$ contents were between 89.4-136.6 mg/kg. The Ca contents were between $7.75-26.99 \mathrm{mg} / \mathrm{kg}$. The $\mathrm{Na}$ contents were between $5.80-18.43 \mathrm{mg} / \mathrm{kg}$. The Fe contents were between $1.08-6.32 \mathrm{mg} / \mathrm{kg}$. The $\mathrm{Zn}$ contents were between $0.10-5.89 \mathrm{mg} / \mathrm{kg}$. The B contents were between $88.51-136.6 \mathrm{mg} / \mathrm{kg}$. The $\mathrm{Mn}$ contents were between $0.24-0.89 \mathrm{mg} / \mathrm{kg}$. The $\mathrm{Cu}$ contents were between $0.20-0.72 \mathrm{mg} / \mathrm{kg}$. The Li contents were between $0.012-0.027 \mathrm{mg} / \mathrm{kg}$. The Se content were between $0.001-$ $0.041 \mathrm{mg} / \mathrm{kg}$.

\subsection{Nutrient Content and Sensory Evaluation Score of Olecranon Peaches}

According to 1.4 and 1.5 methods, the nutritional contents and sensory evaluation of the fruit were determined. The results were shown in Fig.13-15.

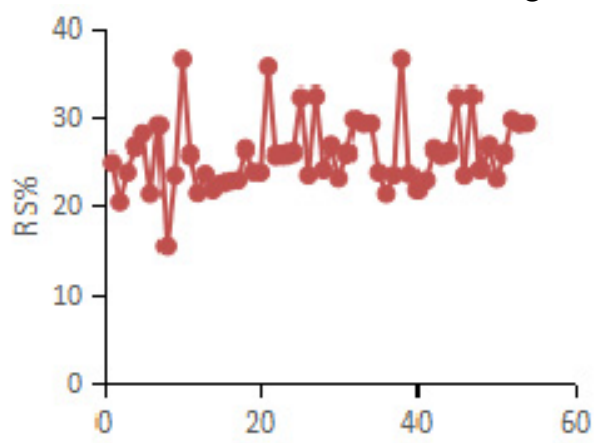

Fig.13 Contents of RS\% in 54 samples

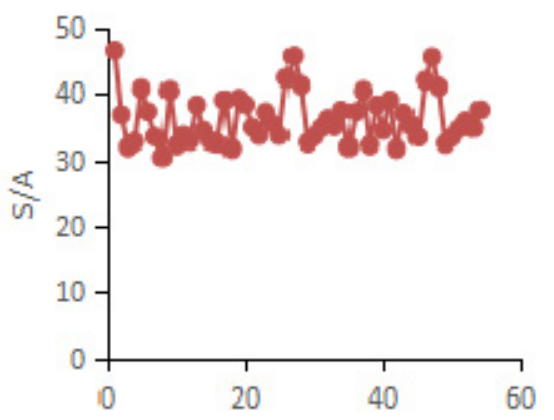

Fig.14 Contents of S/A in 54 samples

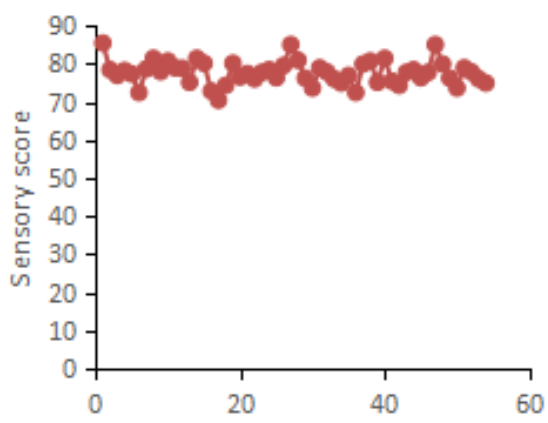

Fig .15 Sensory evaluation scores of 54 samples

From the Fig.13-15, we can see that the ratios of reducing sugar $(\mathrm{RS} \%)$ were $15.47 \%-36.43 \%$. The ratios of sugar to acid were 30.46-46.61. And the scores of sensory evaluation were 70.4-85.4.

\subsection{Correlation analyses}

The composition of mineral elements, $\mathrm{RS} \%, \mathrm{~S} / \mathrm{A}$ and sensory evaluation of 54 samples were divided into independent variables. Using SPSS 23.0 software, pearson correlation was used to establish the correlation analysis between mineral elements, $\mathrm{RS} \%, \mathrm{~S} / \mathrm{A}$ and sensory evaluation score. The results were shown in table 3.

Table 3 showed that, $\mathrm{K}$ contents and $\mathrm{P}, \mathrm{Mg}$ contents were significantly positively correlated. The $\mathrm{P}$ contents were positively correlated with the $\mathrm{K}, \mathrm{Mg}$ contents and negatively correlated with the S/A contents. The $\mathrm{Mg}$ contents were positively correlated with the K, P, Na contents. And it had a significant positive correlation with $\mathrm{B}, \mathrm{Li}$ contents. The $\mathrm{Ca}$ contents were positively correlated with the $\mathrm{Zn}$ contents. And it had a significant positive correlation with $\mathrm{Li}$ contents. The $\mathrm{Na}$ contents were positively correlated with the $\mathrm{Mg}, \mathrm{Mn}$ contents. And it had a significant positive correlation with $\mathrm{Cu}$ contents. The $\mathrm{Zn}$ contents were positively correlated with the $\mathrm{Ca}, \mathrm{Cu}$ contents. And it had a significant negative correlation with $\mathrm{B}$ contents. The $\mathrm{B}$ contents were positively correlated with the $\mathrm{Mg}$ contents. And it had a significant negative correlation with $\mathrm{Zn}$ contents. The Mn contents were positively correlated with the $\mathrm{Na}$ contents. And it had a significant positive correlation with $\mathrm{RS} \%$ ratios. The $\mathrm{Li}$ contents were positively correlated with the $\mathrm{Mg}, \mathrm{Ca}$ contents. The $\mathrm{Cu}$ contents were positively correlated with the $\mathrm{Zn}$ contents. And it had a significant positive correlation with $\mathrm{Na}$ contents, 
also had a significant negative correlation with Se contents. The Se contents and the $\mathrm{Cu}$ contents were significantly negative correlation. And there were significant positive correlation between reducing sugar contents and $\mathrm{Mn}$ contents. A significant negative correlation was exited between sugar-acid ratios and $\mathrm{P}$ contents, it was positively correlated with the senses.

\section{Conclusions}

Table 3 Correlation between mineral element content and nutrient content and sensory evaluation of Olecranon Peaches

\begin{tabular}{|c|c|c|c|c|c|c|c|c|c|c|c|c|c|c|c|c|c|}
\hline & & Serial number & $\mathrm{K}$ & $\mathrm{P}$ & $\mathrm{Mg}$ & $\mathrm{Ca}$ & $\mathrm{Na}$ & $\mathrm{Fe}$ & $\mathrm{Zn}$ & B & $\mathrm{Mn}$ & $\mathrm{Li}$ & $\mathrm{Cu}$ & $\mathrm{Se}$ & RS\% & S/A & Senses \\
\hline Serial number & Correlation & 1 & $-.394^{* *}$ & -.063 & -.209 & -.232 & .089 & -.024 & -.056 & -.247 & -.057 & .133 & $-.352^{* *}$ & -.099 & .235 & .052 & -.112 \\
\hline K & Correlation & $-.394^{* *}$ & 1 & $.416^{* *}$ & $.713^{* * *}$ & .125 & .252 & -.083 & -.108 & .184 & .080 & .058 & .107 & .148 & -.021 & .049 & .258 \\
\hline$P$ & Correlation & -.063 & $.416^{* *}$ & 1 & $.553^{* * *}$ & -.002 & .205 & .079 & -.139 & .182 & .182 & .185 & .141 & .060 & -.175 & $-.273^{*}$ & -.126 \\
\hline $\mathrm{Mg}$ & Correlation & -.209 & $.713^{* *}$ & $.553^{* *}$ & 1 & .158 & $.354^{* *}$ & -.143 & -.145 & $.268^{*}$ & .069 & $.274^{*}$ & .195 & -.076 & -.012 & -.098 & .044 \\
\hline $\mathrm{Ca}$ & Correlation & -.232 & .125 & -.002 & .158 & 1 & .038 & .003 & $.380^{* *}$ & -.159 & -.121 & $.268^{*}$ & .235 & -.237 & -.107 & -.175 & -.240 \\
\hline $\mathrm{Na}$ & Correlation & .089 & .252 & .205 & $.354^{* *}$ & .038 & 1 & -.126 & .188 & .055 & $.373^{* *}$ & .189 & $.335^{*}$ & -.162 & -.009 & .088 & -.058 \\
\hline $\mathrm{Fe}$ & Correlation & -.024 & -.083 & .079 & -.143 & .003 & -.126 & 1 & -.002 & -.183 & .246 & -.159 & -.020 & -.085 & -.041 & -.110 & -.162 \\
\hline $\mathrm{Zn}$ & Correlation & -.056 & -.108 & -.139 & -.145 & $.380^{* *}$ & .188 & -.002 & 1 & $-.288^{*}$ & -.044 & .239 & $.392^{* *}$ & -.215 & -.065 & .142 & -.241 \\
\hline B & Correlation & -.247 & .184 & .182 & $.268^{*}$ & -.159 & .055 & -.183 & $-.288^{*}$ & 1 & .062 & .052 & .005 & .123 & -.177 & .155 & .199 \\
\hline Mn & Correlation & -.057 & .080 & .182 & .069 & -.121 & $.373^{* *}$ & .246 & -.044 & .062 & 1 & .050 & .079 & .082 & $.302^{*}$ & -.001 & .034 \\
\hline $\mathrm{Li}$ & Correlation & .133 & .058 & .185 & $.274^{*}$ & $.268^{*}$ & .189 & -.159 & .239 & .052 & .050 & 1 & .182 & -.142 & .153 & -.129 & -.169 \\
\hline $\mathrm{Cu}$ & Correlation & $-.352^{* *}$ & .107 & .141 & .195 & .235 & $.335^{*}$ & -.020 & $.392^{* *}$ & .005 & .079 & .182 & 1 & $-.410^{* *}$ & -.205 & .113 & -.150 \\
\hline $\mathrm{Se}$ & Correlation & -.099 & .148 & .060 & -.076 & -.237 & -.162 & -.085 & -.215 & .123 & .082 & -.142 & $-.410^{* *}$ & 1 & -.031 & -.186 & .210 \\
\hline $\mathrm{RS} \%$ & Correlation & .235 & -.021 & -.175 & -.012 & -.107 & -.009 & -.041 & -.065 & -.177 & $.302^{*}$ & .153 & -.205 & -.031 & 1 & -.005 & .174 \\
\hline $\mathrm{S} / \mathrm{A}$ & Correlation & .052 & .049 & $-.273^{*}$ & -.098 & -.175 & .088 & -.110 & .142 & .155 & -.001 & -.129 & .113 & -.186 & -.005 & 1 & $.368^{* *}$ \\
\hline Senses & Correlation & -.112 & .258 & -.126 & .044 & -.240 & -.058 & -.162 & -.241 & .199 & .034 & -.169 & -.150 & .210 & .174 & $.368^{* *}$ & 1 \\
\hline
\end{tabular}

In this paper, the contents of mineral elements (including $\mathrm{K}, \mathrm{P}$, $\mathrm{Mg}, \mathrm{Ca}, \mathrm{Na}, \mathrm{Fe}, \mathrm{Cu}, \mathrm{Mn}, \mathrm{B}, \mathrm{Zn}, \mathrm{Se}, \mathrm{Li}$ ) in 54 Olecranon Peaches were collected. Reducing sugar(RS), total soluble sugar (S) and titratable acid (A) were determined by the National Standard. The correlation analysis (CA) was carried out by SPSS 23.0 software to find out the mineral elements and nutrient components significantly related to the sensory evaluation of Olecranon Peaches. The results showed that in the tested samples, it had a significant positive correlation between S/A sugar-acid ratio and sensory evaluation. S/A was negatively correlated with $\mathrm{P}$ contents. The P contents were positively correlated with the $\mathrm{K} 、 \mathrm{Mg}$ contents. The Mg contents were positively correlated with the $\mathrm{K} 、 \mathrm{Na}$ contents. The $\mathrm{Na}$ contents were positively correlated with the $\mathrm{Mn}$ contents. The contents of $\mathrm{Mn}$ were positively correlated with $\mathrm{RS} \%$ ratios of reducing sugar.

Systematic studies on the relationship between mineral elements, nutritional components and sensory evaluation of Olecranon Peaches were few. This paper is just a simple preliminary study. Further research is needed to collect relevant data for different years in order to establish a complete and reliable correlation model.

\section{Acknowledgment}

Project Support: Scientific Research Project of Guangdong Provincial Bureau of market supervision (2019ZZ08); Scientific Research Project of Heyuan Polytechnic(2020KJ-07)

\section{References}

1. Lu Baoxin, Ma Nan, Wang Xia, et al. Tracing the Geographical Origin of Soybeans Based on Inductively Coupled Plasma Mass Spectrometry (ICP-MS) Analysis of Mineral Elements [J]. Food Science, 2018, 39(8): 288-294.

2. Borges E M, Gelinski J M L N, de Oliveira Souza V C, et al. Monitoring the authenticity of organic rice via chemometric analysis of elemental data[J]. Food Research International, 2015, 77: 299-309.

3. Zhao H, Guo B, Wei Y, et al. Effects of wheat origin, genotype, and their interaction on multielement fingerprints for geographical traceability[J]. Journal of Agricultural \& Food Chemistry, 2012, 60(44):10957-62.

4. Zheng hui. Research on Confirmation of Liuhe Rice Producing Area Based on Mineral Element Fingerprinting Technique[D]. Jilin Agricultural University, 2018.

5. Zhang Yue, Wang Zhaohui, Zhang Yating, et al. The Provenance Traceability of $R$ ice Based on the Principal Component Analysis and Discriminant Analysis[J]. Journal of the Chinese Cereals and Oils Association, 2016,31 (4):1-5

6. Dang L M. Minerals in milk powders of different regional origin: A preliminary study[D].Dissertations \& Theses - Gradworks, 2009. 
7. Zhao Qian. Study on the Confirmation of Producing Area of Meihe Rice by Applying Mineral Element Technology [D]. Jilin Agricultural University, 2018.

8. Wang Kaiqiang. Traceability Technique Study on Organic Pork based on Fatty Acid and Characteristic Markers related to ${ }^{1} \mathrm{H}-\mathrm{NMR}[\mathrm{D}]$. Chinese Academy of Agricultural Sciences,2015.

9. Liu Wenjing. Origin Traceability of Soybean Based on Soybean Isoflavone Features[D]. Heilongjiang Bayi Agricultural University,2018. 